Acta Crystallographica Section A

Foundations of Crystallography

ISSN 0108-7673

Received 8 October 2007

Accepted 23 November 2007

\section{An easy non-invasive $X$-ray diffraction method to determine the composition of Na-pyroxenes from high-density 'greenstone' implements}

\author{
Roberto Giustetto, ${ }^{\mathrm{a} *}$ Giacomo Chiari $^{\mathrm{b}}$ and Roberto Compagnoni ${ }^{\mathrm{a}}$ \\ ${ }^{a}$ Dip. Scienze Mineralogiche e Petrologiche, Università di Torino, 35 Via Valperga Caluso, 10125 \\ Torino, Italy, and ${ }^{\mathbf{b}}$ Getty Conservation Institute, 1200 Getty Centre Drive, Suite 700, Los Angeles, \\ CA 90049-1684, USA. Correspondence e-mail: roberto.giustetto@unito.it
}

\begin{abstract}
A large number of polished stone implements from Palaeolithic to Bronze Age sites of Northern Italy and Southern France are made of high-pressure (HP) metamorphic rocks (eclogite and related rocks), mainly consisting of Napyroxene (jadeite to omphacite) from the metamorphic belt of the Western Alps. The standard archaeometric study of prehistoric stone implements follows a procedure that is invasive, expensive and time-consuming. Since Na-pyroxenes may show a large compositional range, a thorough study of the variations affecting the $d_{h k l}$ values, obtained by X-ray diffraction, of three selected reflections as a function of different chemical composition was carried out, in order to determine the chemistry of Na-pyroxene isomorphic mixtures and roughly evaluate their relative amounts. These reflections $(\overline{2} 21,310,002)$ are sharp, intense and sensitive to the variation of pyroxene chemical composition. Using such $d_{h k l}$ values measured on pyroxenes of known chemistry, a Ca-pyroxene(Di)-jadeite(Jd)-aegirine(Ae) compositional diagram was constructed, from which the composition of an unknown pyroxene can be estimated within an error of about $5 \%$. When the size of the object is relatively small and a flat polished surface is present, the proposed analytical procedure becomes totally non-invasive. The data obtained shed light on the provenance sources of such implements and the prehistoric trade routes.
\end{abstract}

\section{Introduction}

A great number of Neolithic stone implements (mostly axes see Fig. 1 - but also chisels and decorative objects such as rings and pendants) have been found in various archaeological sites all over Italy. In Southern Italy, fine-grained basalt rocks were used, while andesite prevailed in the North East. Those who inhabited the flat lands near the Alpine chain, the currently named Po river plain, had at their disposal better raw materials: 'Pietra Verde Alpina' or 'Alpine Green Stones' (hereafter AGS). This term is commonly used to describe a group including a limited variety of lithotypes, selected by our ancestors because of their peculiar toughness, high density, resistance to shock and abrasion, and high durability.

The relative abundance of AGS implements led to the supposition that these had an exotic origin, since analogous materials were reported both in the Mayan (Lange, 1993; Sharer \& Morley, 1995) and Chinese (Laufer, 1946) cultures but were unknown in the Alpine geological context. Gastaldi (1871) first hypothesized their autochthon provenance and Damour (1881) and Franchi (1900) reported the existence of analogous lithic material in very limited outcrops from the Piemonte zone, Western Alps. Further studies (Ricq-de-
Bouard, 1981, 1996; Ricq-de-Bouard et al., 1990; D’Amico et al., 1991) confirmed the Alpine origin of these materials. Petrographic studies performed on AGS axes showed that

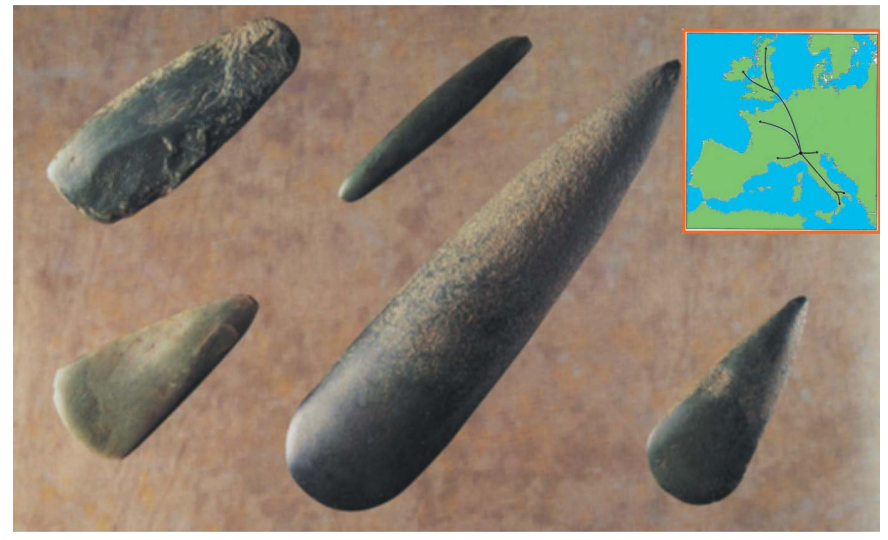

Figure 1

Examples of Neolithic implements perfectly preserved. (From Le Vie della Pietra Verde. L'Industria Litica Levigata nella Preistoria dell'Italia Settentrionale (1996), edited by M. Venturino Gambari ). In the insert the main paths through Europe of greenstone coming from Piedmont is shown. 
these rocks are fine to very fine grained and different from similar coarser-grained lithologies from the Western Alps, well known since they have been mapped and studied by geologists (see e.g. D'Amico et al., 1995).

Archaeological evidence showed that these tools covered long distances, probably as a result of trade among different tribes. Polished AGS implements were found in Southern France and along a wide corridor that runs from Southern Italy to the British Isles (see insert in Fig. 1) (Petrequin et al., 2002). D'Amico et al. (1991, 1995, 1997, 2000; D'Amico \&

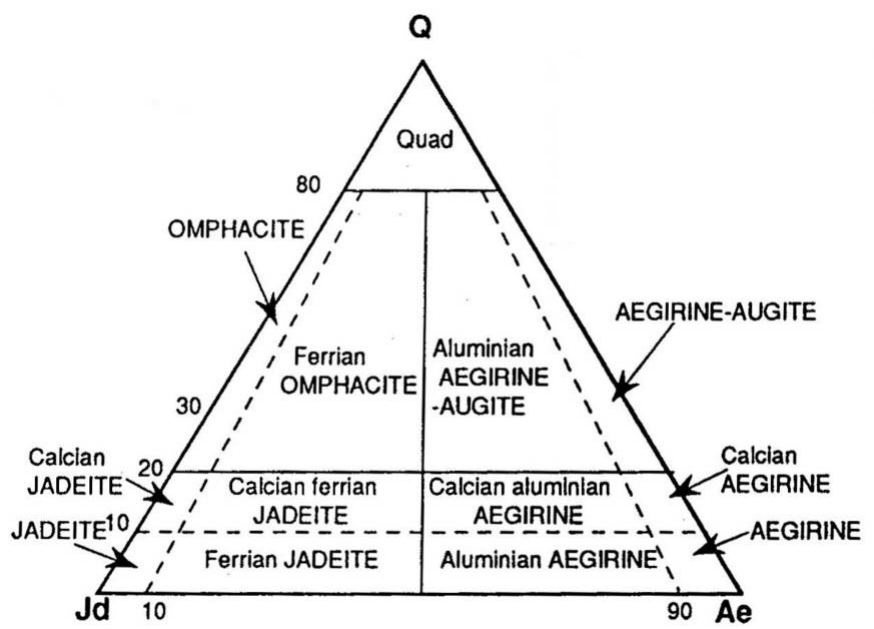

Figure 2

Classification of Na-pyroxenes according to Rock (1990): $\mathrm{Q}=$ wollastonite + enstatite + ferrosilite $; \mathrm{Jd}=$ jadeite $; \mathrm{Ae}=$ aegirine .
Ghedini, 1996; D'Amico \& Starnini, 2006) and Compagnoni et al. (1995), who systematically analysed a great number of stone implements collected in several archaeological sites of Northern Italy, concluded that AGS are predominant ( $>90 \%)$ in the Western Alps and Po river plain, but become progressively less important on moving away from such areas. The archaeometric study of such implements is aimed at locating the primary outcrops of the raw materials, thus allowing reconstruction of the prehistoric trade routes followed by our ancestors (Giustetto \& Compagnoani, 2004). Unfortunately, such a procedure is expensive, time-consuming and even destructive. An innovative technique, based solely on X-ray diffraction data (XRD), was therefore conceived, in order to determine the minero-chemical composition of such tools and to obtain the same archaeometric data, with an eye towards preserving their integrity.

\section{The raw materials}

AGS rocks are derived from the subducted oceanic lithosphere and include a wide spectrum of lithologies, indicated as high-pressure metamorphic rocks (hereafter HPMR). This lithologic group includes all rock types with roughly 'mafic' (basalt/gabbro) compositions, usually in close association with serpentinites. Since serpentinite, due to its ubiquitous distribution, appears to be useless to infer the provenance area, the other associated HPMR are usually studied instead.

The AGS originating from the Alpine belt (usually the Western Alps) include eclogites (term coined by R. J. Hauy,
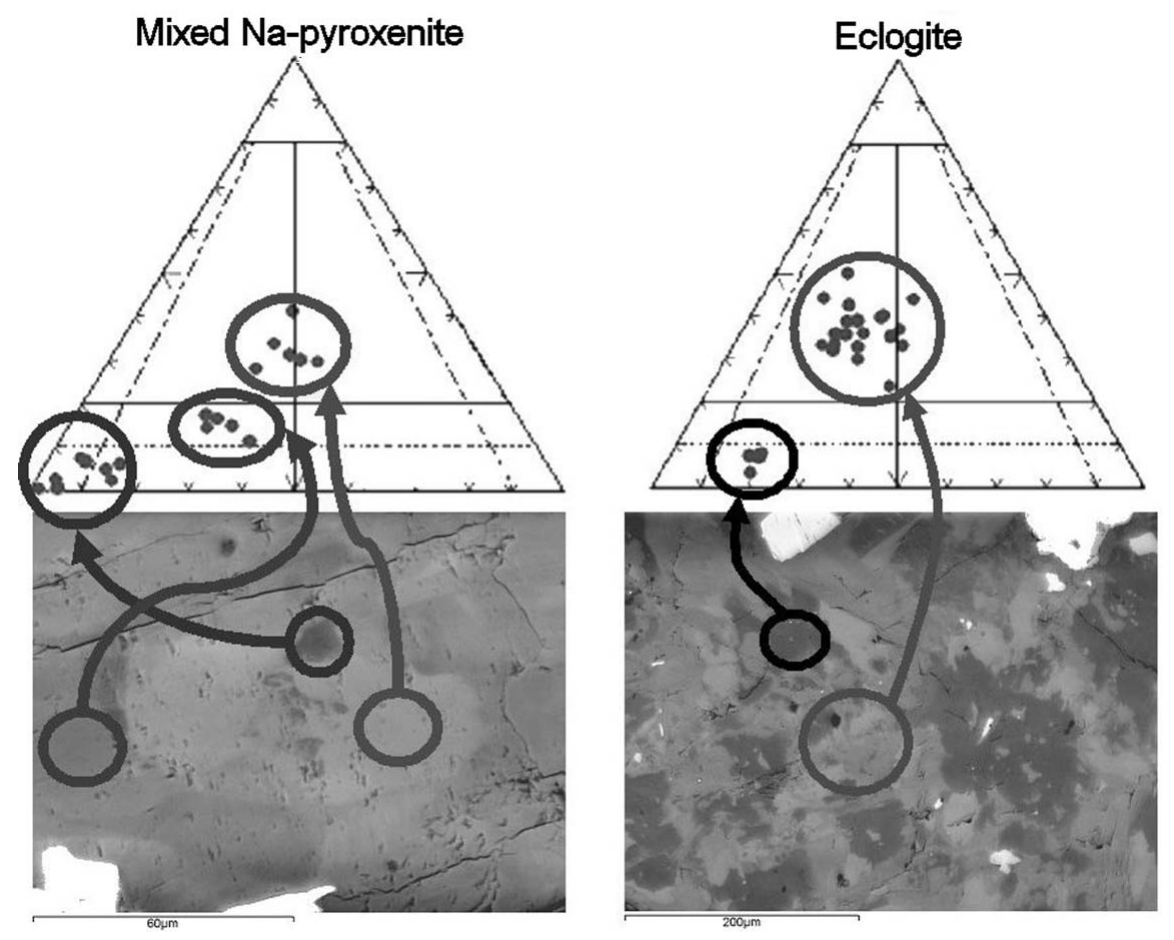

Figure 3

SEM-EDS back-scattered electron images of Na-pyroxenes from Na-pyroxenites and eclogites: different shades of grey correspond to different chemical compositions. 
Table 1

Cell parameters of clinopyroxenes.

\begin{tabular}{llllllll}
\hline Na-pyroxene & Formula & $a(\AA)$ & $b(\AA)$ & $c(\AA)$ & $\beta\left(^{\circ}\right)$ & Cell volume $\left(\AA^{3}\right)$ & Reference \\
\hline Jadeite & $\mathrm{NaAlSi}_{2} \mathrm{O}_{6}$ & $9.42(3)$ & $8.56(2)$ & $5.22(3)$ & $107.56(3)$ & 402.15 & ICSD database \\
Aegirine & $\mathrm{NaFeSi}_{2} \mathrm{O}_{6}$ & $9.66(4)$ & $8.80(2)$ & $5.30(4)$ & $107.39(5)$ & 429.8 & Davoli (1986) \\
Diopside & $\mathrm{CaMgSi}_{2} \mathrm{O}_{6}$ & $9.74(3)$ & $8.92(3)$ & $5.25(4)$ & $105.90(2)$ & 439.1 & ICSD database \\
Hedenbergite & $\mathrm{CaFeSi}_{2} \mathrm{O}_{6}$ & $9.85(5)$ & $9.02(4)$ & $5.24(4)$ & $104.74(3)$ & 450.6 & Cameron \& Papike (1981) \\
\hline
\end{tabular}

1822) and Na-pyroxenites [jadeitites, omphacitites and mixed Na-pyroxenites (Compagnoni et al., 2006)].

Na-pyroxenes, the main silicate mineral phases, show a complex chemistry due to the large number of cations, which can distribute over the three crystallographic sites as $\mathrm{Na}, \mathrm{Al}$, $\mathrm{Fe}^{2+}, \mathrm{Fe}^{3+}, \mathrm{Ca}, \mathrm{Mg}, \mathrm{Cr}^{3+}, \mathrm{Ti}^{4+}, \mathrm{Mn}^{2+}$ and even $\mathrm{K}$ (Bindi et al., 2003).

When pyroxenes from the Alpine HPMR are concerned, the following end-members are generally considered: jadeite (Jd: $\mathrm{NaAl}\left[\mathrm{Si}_{2} \mathrm{O}_{6}\right]$ ), aegirine (Ae: $\mathrm{NaFe}^{3+}\left[\mathrm{Si}_{2} \mathrm{O}_{6}\right]$ ), wollastonite (Wo: $\mathrm{Ca}\left[\mathrm{SiO}_{3}\right]$, enstatite (En: $\mathrm{Mg}\left[\mathrm{SiO}_{3}\right]$ ) and ferrosilite (Fs: $\left.\mathrm{Fe}\left[\mathrm{SiO}_{3}\right]\right)$. In addition, a further intermediate term \{omphacite: $\left.(\mathrm{Ca}, \mathrm{Na})\left(\mathrm{Mg}, \mathrm{Al}, \mathrm{Fe}^{2+}\right)\left[\mathrm{Si}_{2} \mathrm{O}_{6}\right]\right\}$ is commonly used.

A triangular diagram (Rock, 1990) (see Fig. 2) is adopted to express the chemical composition of pyroxenes as percentages of three different end-members [Jd, Ae and a third cumulative term $(\mathrm{Wo}+\mathrm{En}+\mathrm{Fs}$ or $\mathrm{Q})]$.

\section{Conventional archaeometric approach}

A standard procedure to characterize the AGS implements was codified by Chiari, Compagnoni, Giustetto \& Ricq-deBouard (1996). It includes several techniques giving progressively more detailed information: (i) macroscopic examination shows grain size, chromatic heterogeneities and sometimes mineralogical features; (ii) density measurements discriminate low-density lithotypes (such as serpentinite, $\delta<2.60$, and prasinite, $\delta<3.00$ ) from HPMR and garnet-bearing rocks (eclogites, $\delta>3.00$ ). These density ranges are reliable only if the HPMR are not affected by greenschist-facies retrogression, which produces lower-density minerals such as albite; (iii) X-ray powder diffraction (XRPD) gives the mineralogical composition and roughly quantifies the coexistence of pyroxenes with different compositions; (iv) the microscopic analysis of thin sections (30 $\mu \mathrm{m}$ thick) with both optical and scanning electron microscopes (SEM) equipped with an energy-dispersive spectrometer (EDS) is the most exhaustive technique. Owing to the complex zoning and extreme chemical heterogeneity, a significant number of spot analyses must be collected. Usually, the plotted points spread over a large area (Fig. 3): the compositional heterogeneity of pyroxenes, evidenced by their different contrast (ranging from pale to dark grey), is pointed out by the distribution in different areas of the related point EDS analysis, each corresponding to a particular chemistry.

The application of XRPD and especially SEM-EDS accurately describes the lithic material, but has a high cost and requires the skill of qualified operators. In addition, the integrity of the artefacts is undermined: while high-quality XRPD data can be collected on very small samples (a few $\mathrm{mg}$ ) or directly on flat surfaces of small objects, SEM-EDS needs drill cores (at least $10 \mathrm{~mm}$ across) to be sampled for a representative thin section.

Recently Errera (1999, 2002), using diffuse reflectance UVVIS-NIR spectroradiometry, classified AGS implements according to their mineralogy. Such a non-invasive method can be applied with a portable device, but its results are often dubious since different mineralogical associations may give similar patterns. Spectroradiometry proved to be a valid approach when coupled with other techniques but provided poor information when considered alone (Errera, 2002).

\section{Development of a new analytical method}

Most implements (mainly axes) from the early Neolithic to the Bronze Age are made of fresh eclogite and Na-pyroxenite raw materials. Since in these rocks single Na-pyroxene crystals may be zoned and/or two or more pyroxenes with different composition may coexist (Fig. 3), it is of paramount importance to determine the compositional range and the relative amount of the minerals present.

The cell parameters of clinopyroxenes vary regularly as a function of the chemical composition: unit-cell parameters $a$ and $b$ progressively increase from $\mathrm{Na}(\mathrm{Jd}$ and $\mathrm{Ae}$ ) to $\mathrm{Ca}$-rich [diopside (Di): $\mathrm{CaMgSi}_{2} \mathrm{O}_{6}$; hedenbergite (Hd): $\mathrm{CaFe}^{2+} \mathrm{Si}_{2} \mathrm{O}_{6}$ ] end-members, while $\beta$ shows the opposite trend. The $c$ variations are less pronounced and tend to increase according to the sequence Jd-Hd-Di-Ae (Table 1). Intermediate compositions show cell-parameter values comprised within those of the end-members.

Edgar et al. (1969) tried to correlate the clinopyroxene cell parameters to their chemical compositions. They assumed the range of variation of cell parameters among the end-members to be constant and traced multiple series of regularly spaced isoparametric lines on a triangular diagram. They obtained a 'compositional grid' in which three families of lines (each related to a single parameter) were variably oriented with respect to each other. The chemical composition of a given member of the isomorphic series, with known cell parameters, could be estimated by locating on the diagram the intersection of lines characterized by the experimentally measured $a, b$ and $c$ values.

A compositional grid for clinopyroxenes based on the cellparameter variations presents several difficulties. First of all, both $a$ and $b$ show similar trends of variation: this would cause the corresponding families of isoparametric lines to intersect 
at low angles, enlarging the error of composition estimate. In a useful grid, each family of lines should have a characteristic orientation, different from the others, the optimum being to intersect at right angles. In addition, the narrow range of variation for the $c$ parameter causes adjacent lines to be excessively spaced for obtaining reliable estimates. Furthermore, for an accurate measurement of the cell parameters, many diffraction peaks need to be measured and indexed in order to be treated by a least-squares procedure. This may be difficult to obtain given the peak superposition due to the simultaneous presence of very similar minerals.

An analogous dependence from chemical composition may be observed in the variations affecting some selected $d$ values. The measurement of a given $d$ is faster and easier than that of the unit cell, implying a significant simplification in the procedure.

Ernst et al. (1970) proposed a compositional grid based on the variations of both cell parameters and selected $d$ values. Their results showed that the variations of $d$ values from a clinopyroxene with a given chemical composition may not be constant across the compositional triangle, as evident from the lack of parallelism among the related isoparametric lines.

In an attempt to improve this procedure, a thorough study of the variations affecting the $d$ values of selected reflections as a function of different chemical composition of clinopyroxenes was carried out in this study. Particular care was taken in selecting the proper reflections: they should be sensitive to chemical variations, intense and presenting scarce overlapping, so that their $d$ values can easily be measured even in the presence of minerals of similar composition. The $d$ values for each end-member were evaluated, in order to choose those showing larger variations. High $2 \theta$ for a precise measurement of the $d$ and high intensity were favoured.

The two strongest reflections, namely $\overline{2} 21$ and 310, were chosen (Fig. 4), being well separated and quite close $(27<2 \theta<$ $34^{\circ}$, using $\mathrm{Cu} K \alpha$ radiation). Both $d_{221}$ and $d_{310}$ values show significant variations all over the solid-solutions series, passing from 2.916 and $2.829 \AA$ (Jd) to 2.993 and $2.950 \AA$ (Wo + En +

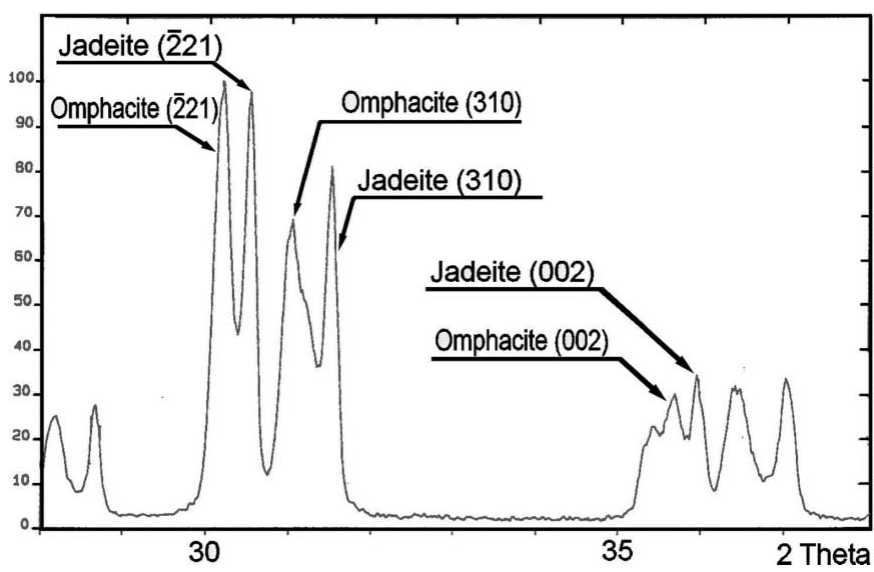

Figure 4

XRPD pattern of a mixed Na-pyroxenite between 28 and $38^{\circ} 2 \theta$, the angle interval which contains the three most significant reflections for Na-pyroxenes.
Fs), respectively, with intermediate values for Ae. Unfortunately, both $d_{221}$ and $d_{310}$ are dependent mostly on $a$ and $b$ so that their isoparametric lines are close to parallel. A third reflection is therefore needed. After a careful search, 002 was selected, dependent upon $c \sin \beta$ only, which shows a completely different trend and is reasonably close to the other two $\left(35<2 \theta<38^{\circ}\right.$, using $\mathrm{Cu} K \alpha$ radiation). The 002 diffraction peak is not as intense as $\overline{2} 21$ and 310 , nor are its $d$ variations as pronounced as those of the other two peaks (from $2.487 \AA$ in Jd to $2.531 \AA$ in Ae, with Wo + En + Fs showing intermediate values); furthermore, its position is such that it may occasionally be overlapped by peaks of other coexisting minerals. In spite of these disadvantages, the 002 peak proved to be the best possible choice.

A wide literature search was performed to find reliable crystal-chemical data. Single-crystal studies were preferred, as they provide accurate cell parameters and quasi-homogeneous chemical compositions. More than one hundred Na-clinopyroxene data from single-crystal structural determination (Edgar et al., 1969; Griffin \& Mottana, 1982; Mottana, 1983; Davoli, 1986; Pasqual et al., 1995; Oberti, personal communication; Boffa Ballaran et al., 1998; Nestola et al., 2006, 2007) were projected on the triangular diagram according to their chemical compositions; no literature data were located in the aegirine-augite compositional field, suggesting the probable presence of a miscibility gap. Three different sets of isoparametric lines - for the reflections 221,310 and 002 , respectively - were traced, by interpolating points related by the same (or very similar) $d$ values with straight lines or curves. The resulting compositional grid is shown in Fig. 5.

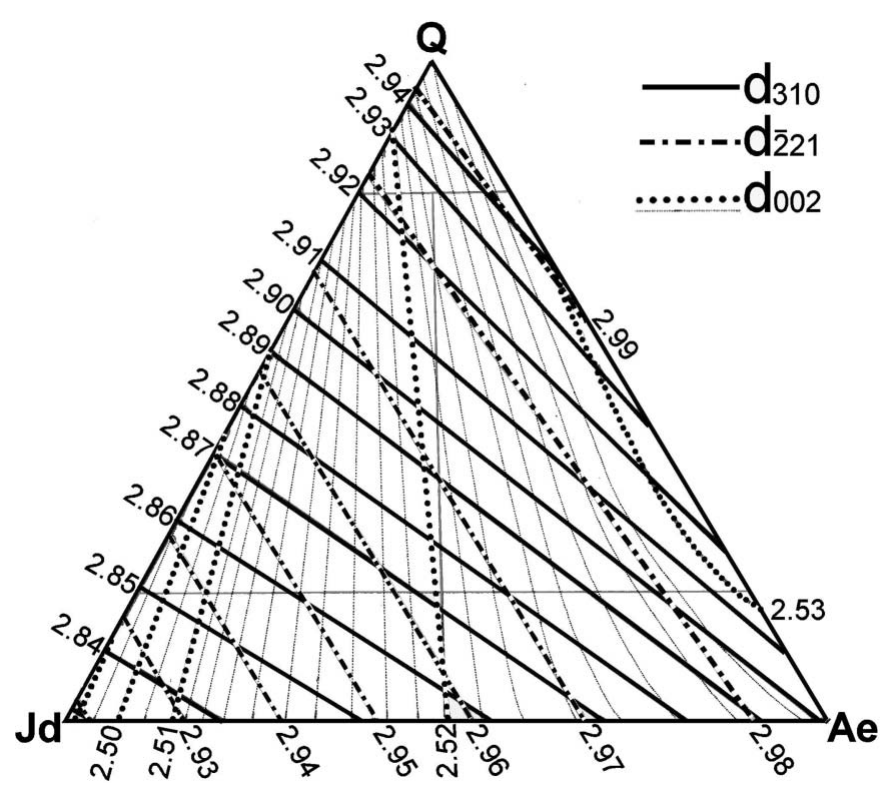

Figure 5

Compositional grid for Na-pyroxenes, resulting from the intersection of three different sets of isoparametric lines, each related to a significant reflection, superposed on the classification diagram by Rock (1990). The chemical composition of a given Na-pyroxene may be estimated from the intersection of the three measured $d_{h k l}$ values. 
Table 2

Range of variation for cell parameters in jadeite and omphacite.

\begin{tabular}{lll}
\hline Parameter & Jadeite & Omphacite \\
\hline$a$ & $9.42-9.51 \AA$ & $9.54-9.66 \AA$ \\
$b$ & $8.56-8.64 \AA$ & $8.70-8.81 \AA$ \\
$c$ & $5.22-5.27 \AA$ & $5.24-5.28 \AA$ \\
$\beta$ & $107.3-107.6^{\circ}$ & $106.7-107.5^{\circ}$ \\
Cell volume & $402-412 \AA^{3}$ & $417-427 \AA^{3}$ \\
\hline
\end{tabular}

One can state: (i) as expected, the $d_{\overline{2} 21}$ and $d_{310}$ lines show similar trends. Variations of the $d$ values are quite regular within these families, as shown by similar spacing between adjacent lines; (ii) the $d_{002}$ variation is somewhat irregular, being relevant for jadeite, Ca-jadeite and Fe-jadeite compositions (from 2.487 to $2.510 \AA$ ) but progressively decreasing as the $\mathrm{Fe}$ content increases (the isoparametric lines diverge towards the Ae edge); (iii) some $d_{002}$ lines are curved, which is evidence for a non-linear correlation with chemical composition; (iv) the 310 and 002 lines intersect at approximately right angles near the Jd edge and remain almost orthogonal in other areas too.

The estimate of a clinopyroxene chemical composition can be derived from the intersection of the isoparametric lines characterized by the experimentally measured $d$ values. As a rule, the cross between $d_{310}$ and $d_{002}$ may be preferred, since the related lines show the most suitable intersecting angles. Nevertheless, the third distance $\left(d_{\overline{2} 21}\right)$ can be used to quantify the error affecting the results: by coupling the three $d$ values two-by-two, three separate points can be drawn on the grid, enclosing a triangular area into which the most probable chemical composition of the sample should lie: the larger the area, the bigger the error affecting the estimate.

The internal consistency of the proposed method was checked on literature data derived from single-crystal-structure refinements, affected by small errors, by comparing the

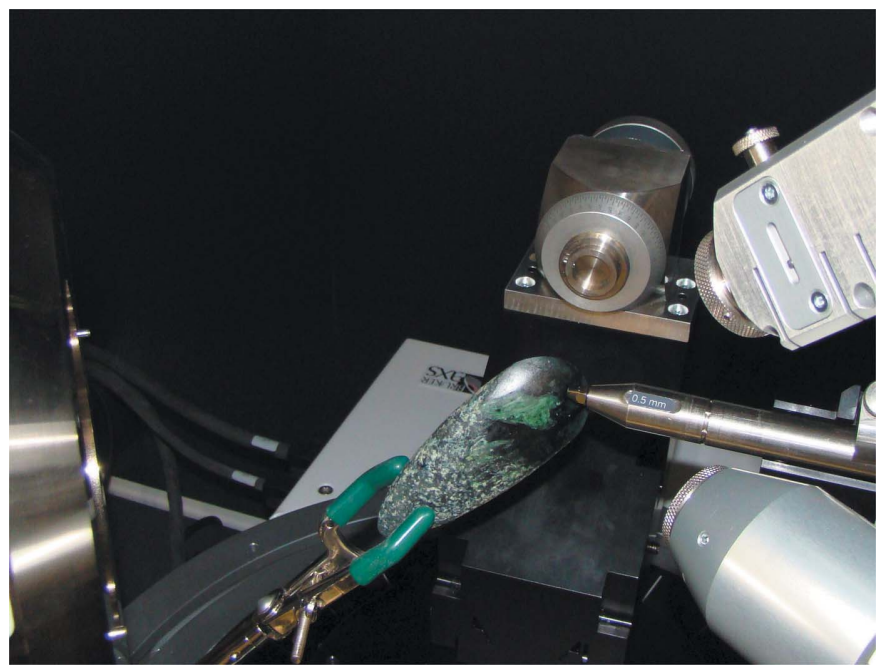

Figure 6

Non-invasive XRD measurement obtained directly on the flat surface of an axe, without sampling (Bruker Gadds instrument). observed and calculated percentages of jadeite. The best-fit line showed an excellent agreement between observed and estimated values, with an error of less than $3 \%$ on average.

This compositional grid can be used to determine the chemistry of the clinopyroxene solid-solution series without performing expensive and time-consuming SEM-EDS analyses. Besides, being microinvasive, the method allows for the integrity of the samples to be preserved: no thin section is required, but only a few milligrams of rock powder. Since the three selected reflections of clinopyroxenes $(\overline{2} 21,310,002)$ are located in a relatively small $2 \theta$ interval $\left(27<2 \theta<38^{\circ}\right.$, using $\mathrm{Cu}$ $K \alpha$ radiation), the time taken for $\mathrm{X}$-ray data collection is drastically reduced. The compositional estimates obtained are averaged on the whole sample: such values are extremely difficult to obtain otherwise due to the high heterogeneity and zoning of minerals. In addition, most axes show a flat polished surface with a fine-grained petrographic texture which provides a random distribution of the crystallites. Such areas can be investigated directly using conventional XRD methods, obtaining very reliable data in a totally non-invasive way (Chiari, Compagnoni \& Giustetto, 1996; Chiari, 2000). This procedure (see Fig. 6) also allows for the measurement of different parts of the objects, reducing the drawbacks of the non-homogeneity of the composition that can be severe when sampling a few milligrams only.

\section{Internal consistency of the proposed method}

The reliability of this method was verified through direct comparison with analytical data collected with conventional archaeometric techniques (Chiari, Compagnoni, Giustetto \& Ricq-de-Bouard, 1996) on selected greenstone implements. 28 Neolithic polished greenstone artefacts (6 jadeitites, 4 omphacitites, 5 mixed Na-pyroxenites, 12 eclogites and 1 omphacitic metagabbro) were characterized by means of density measurement, XRPD, optical microscopy and SEMEDS (Occhiena, 1999; Perrone, 1999; Borgogno, 2000). Diffraction data were collected on an automated Siemens D-5000 diffractometer using graphite-monochromated $\mathrm{Cu} \mathrm{K \alpha}$ radiation and a zero-background flat sample holder. Chemical characterization was performed by using a SEM Stereoscan 360 (Cambridge Instruments), equipped with EDS Link Pentafet (Oxford Instruments). The data collected were processed using Inca 200 Microanalysis Suite software, employing a standard ZAF4 correction procedure. Natural minerals were used as standards. Home-developed leastsquares refinement software was used to calculate the cell parameters of clinopyroxenes, whose range of variation for jadeite and omphacite is shown in Table 2.

As stated above, EDS microanalysis gives the chemical composition of selected spots $\left(\right.$ few $\mu \mathrm{m}^{3}$ ) on a thin section surface. Such information, albeit important, does not account for the chemistry of all crystals of a specific solid-solution series. As a result of the crystal zoning, the distribution of the point EDS analyses on the triangular diagram is spread over 
Table 3

Comparisons between average SEM-EDS and XRPD estimated Na-pyroxene compositions.

The average \% error, calculated on the entire population, is indicated for each end-member.

\begin{tabular}{|c|c|c|c|c|c|c|c|c|c|c|}
\hline \multicolumn{2}{|c|}{ Neolithic implement } & \multicolumn{3}{|c|}{$\begin{array}{l}\text { Chemical composition calculated } \\
\text { by averaging all point EDS analyses }\end{array}$} & \multicolumn{3}{|c|}{$\begin{array}{l}\text { Average chemical composition } \\
\text { estimated from XRPD data }\left(d_{\overline{2} 21}, d_{310}, d_{002}\right)\end{array}$} & \multicolumn{3}{|c|}{ Difference } \\
\hline Sample name & Mineral phase & $\mathrm{Jd}$ & $\mathrm{Ae}$ & $\mathrm{Wo}+\mathrm{En}+\mathrm{Fs}$ & $\mathrm{Jd}$ & $\mathrm{Ae}$ & $\mathrm{Wo}+\mathrm{En}+\mathrm{Fs}$ & $\Delta_{\mathrm{Jd}}$ & $\Delta_{\mathrm{Ae}}$ & $\Delta_{\mathrm{Wo}+\mathrm{En}+\mathrm{Fs}}$ \\
\hline COU 155 & Omphacite & $51(9)$ & $22(8)$ & $27(9)$ & $50(2)$ & $20(6)$ & $29(6)$ & -1 & -2 & +2 \\
\hline LIGU 15 & Jadeite & $88(7)$ & $6(3)$ & $6(4)$ & $76(3)$ & $11(6)$ & $13(6)$ & -12 & +5 & +7 \\
\hline LIGU 15 & Omphacite & $47(8)$ & $15(4)$ & $38(7)$ & $36(2)$ & $18(4)$ & $46(4)$ & -11 & +3 & +8 \\
\hline NOR 11 & Omphacite & $38(7)$ & $18(7)$ & $44(10)$ & $30(1)$ & $20(4)$ & $50(4)$ & -8 & +2 & +6 \\
\hline NAR 439 & Jadeite & $96(3)$ & $2(1)$ & $2(1)$ & $95(1)$ & $3(2)$ & $2(2)$ & -1 & +1 & 0 \\
\hline ALBA 16 & Jadeite & $81(5)$ & $7(1)$ & $12(6)$ & $84(2)$ & $7(4)$ & $9(4)$ & +3 & 0 & -3 \\
\hline ALBA 16 & Omphacite & $46(7)$ & $7(2)$ & $47(8)$ & 49 (1) & $8(3)$ & $43(3)$ & +3 & +1 & -4 \\
\hline COU 453 & Omphacite & $44(7)$ & $19(4)$ & $37(5)$ & $45(4)$ & $12(2)$ & $44(6)$ & +1 & -7 & +7 \\
\hline COU 312 & Omphacite & $33(6)$ & $29(5)$ & $38(7)$ & $34(3)$ & $27(7)$ & $40(6)$ & +1 & -2 & +2 \\
\hline ALBA 7 & Jadeite & $88(4)$ & $10(3)$ & $2(6)$ & $84(2)$ & $9(4)$ & $6(2)$ & -4 & -1 & +4 \\
\hline ALBA 7 & Omphacite & 37 (4) & $27(7)$ & $36(5)$ & $54(2)$ & $9(3)$ & $37(2)$ & +17 & -18 & +1 \\
\hline NAR 220 & Omphacite & $44(4)$ & $16(10)$ & $40(9)$ & $52(2)$ & $6(4)$ & $42(4)$ & +8 & -10 & +2 \\
\hline COR 13 & Omphacite & $36(8)$ & $34(8)$ & $30(10)$ & $46(2)$ & $19(5)$ & $35(5)$ & +10 & -15 & +5 \\
\hline BALLOY2 & Jadeite & $99(1)$ & $0(1)$ & $1(2)$ & $92(1)$ & $4(3)$ & $4(3)$ & -7 & +4 & +3 \\
\hline BALLOY2 & Omphacite & $50(10)$ & $10(3)$ & $40(10)$ & $51(1)$ & $7(3)$ & $42(3)$ & +1 & -3 & +2 \\
\hline PIEM 56 & Omphacite & $41(6)$ & $23(5)$ & $36(5)$ & $49(2)$ & $18(8)$ & $33(7)$ & +8 & -5 & -3 \\
\hline PIEM 64 & Omphacite & $52(4)$ & $4(5)$ & $43(5)$ & $49(1)$ & $12(1)$ & $39(2)$ & -3 & +8 & -4 \\
\hline PIEM 64 & Jadeite & $81(6)$ & $3(3)$ & $16(4)$ & $86(1)$ & $7(2)$ & $7(2)$ & +5 & +4 & -9 \\
\hline PIEM 70 & Omphacite & $44(6)$ & $11(3)$ & $45(5)$ & $45(1)$ & $12(1)$ & $43(2)$ & +1 & +1 & -2 \\
\hline PIEM 61 & Omphacite & $39(7)$ & $22(6)$ & $39(7)$ & $39(1)$ & $26(2)$ & $35(2)$ & 0 & +4 & -4 \\
\hline PIEM 61 & Jadeite & $82(9)$ & $11(6)$ & $7(4)$ & $86(2)$ & $6(3)$ & $8(3)$ & +4 & -5 & +1 \\
\hline PIEM 52 & Omphacite & $44(7)$ & $24(12)$ & $31(12)$ & $47(6)$ & $21(9)$ & $32(8)$ & +3 & -3 & +1 \\
\hline PIEM 48 & Omphacite & $46(5)$ & $22(6)$ & $32(7)$ & $54(1)$ & $13(2)$ & $33(2)$ & +8 & -9 & +1 \\
\hline PIEM 48 & Jadeite & 77 (13) & $14(8)$ & $11(6)$ & $86(1)$ & $4(1)$ & $10(1)$ & +9 & -10 & -1 \\
\hline PIEM 41 & Omphacite & 45 (13) & $17(9)$ & $39(15)$ & $50(6)$ & $20(15)$ & $30(14)$ & +5 & +3 & -9 \\
\hline PIEM 41 & Jadeite & $83(5)$ & $9(4)$ & $8(3)$ & $84(2)$ & $6(3)$ & $10(3)$ & +1 & -3 & +2 \\
\hline PIEM 68 & Jadeite & $90(5)$ & $3(2)$ & $7(3)$ & $91(1)$ & $5(2)$ & $4(1)$ & +1 & +2 & -3 \\
\hline PM 77 & Omphacite & $41(4)$ & $13(3)$ & $48(5)$ & $44(4)$ & $11(2)$ & $45(3)$ & +3 & -2 & -3 \\
\hline PM 75 & Omphacite & $41(8)$ & $20(7)$ & $42(7)$ & $44(4)$ & $22(7)$ & $34(9)$ & +3 & +2 & -8 \\
\hline PM 82 & Jadeite & $95(1)$ & $3(1)$ & $2(1)$ & $97(1)$ & $2(1)$ & $1(1)$ & +2 & -1 & -1 \\
\hline PM 82 & Omphacite & $47(7)$ & $18(2)$ & $37(6)$ & $49(9)$ & $21(5)$ & $30(15)$ & +2 & +3 & -7 \\
\hline PM 80 & Jadeite & $82(10)$ & $12(5)$ & $9(7)$ & $95(6)$ & $3(3)$ & $2(2)$ & +13 & -9 & -7 \\
\hline PM 80 & Omphacite & $57(5)$ & $17(3)$ & $28(5)$ & $60(6)$ & $17(4)$ & $25(4)$ & +3 & 0 & -3 \\
\hline PM 79 & Omphacite & $39(3)$ & $20(1)$ & $44(3)$ & $41(2)$ & $16(3)$ & $43(4)$ & +2 & -4 & -1 \\
\hline PM 89 & Omphacite & $27(6)$ & $14(2)$ & $61(6)$ & $28(1)$ & $19(1)$ & $53(1)$ & +1 & +5 & -8 \\
\hline OF 2758 & Omphacite & $45(9)$ & $18(7)$ & $38(5)$ & $52(3)$ & $17(3)$ & $31(6)$ & +7 & -1 & -7 \\
\hline OF 2780 & Omphacite & $38(6)$ & $25(8)$ & $40(3)$ & $34(6)$ & $36(6)$ & $30(12)$ & -4 & +11 & -10 \\
\hline OF 2761 & Omphacite & $39(4)$ & $12(5)$ & 49 (3) & $42(1)$ & $11(1)$ & $47(2)$ & +3 & -1 & -2 \\
\hline Average error & o) calculated for & ach end-n & aber & & & & & $5(4)$ & $5(4)$ & $4(3)$ \\
\hline
\end{tabular}

an area whose extent reflects the chemical heterogeneity of the rock.

It is therefore difficult to compare the SEM-EDS scattered point data with the compositional estimates obtained from $\mathrm{XRD}$, which are averaging the whole rock sample composition. For comparison, the average clinopyroxene composition of each specimen ( $\%$ of each end-member) was calculated over all the point EDS analyses. This procedure allowed us to obtain for each sample a single point (or two points, if both jadeite and omphacite are present) which indicates the prevailing pyroxene compositions. The standard deviation $(\delta)$ of the obtained average compositions reflects the minerochemical heterogeneity of the specimen, high $\delta$ values corresponding to a widespread distribution of the point analyses in the triangular diagram. Although this procedure is partly affected by the choice of the spots to be analysed by SEMEDS, it appeared to be the best way to proceed.
The chemistry of clinopyroxenes estimated from diffraction data was obtained, for each specimen, by projecting the $d_{\overline{2} 21}$, $d_{310}$ and $d_{002}$ values, measured in $\AA$, on the compositional grid. Sharp \% values of each end-member (Jd, Wo + En + Fs, Ae) were obtained by averaging the compositions of the three separate points resulting by combining two-by-two the considered $d_{h k l}$ values.

Comparisons between average EDS compositions and XRPD-derived ones were made, within each specimen, for all end-members. The absolute differences found were averaged over the entire population, with the aim of statistically quantifying the error affecting the compositional end-member estimates. The results are summarized in Table 3. The errors are within an average value of $5 \%$, confirming the consistency of the method.

Fig. 7 shows the reliability of the composition estimated through XRPD for each sample by comparing its position with 
those of all SEM-EDS point analyses. In each diagram (corresponding to a single Neolithic implement), the XRPDestimated compositions for jadeite and/or omphacite are displayed with bigger grey dots; those obtained from SEMEDS with smaller black ones. Note that in most cases the agreement is excellent: the grey dot is plotted within the area defined by the black ones, often in the core. The same procedure was applied to four geological samples, namely a jadeitite, an omphacitite and a Na-pyroxenite from Guatemala (MVJ849b2, MVJ8714-1, MVJ84512), kindly provided by G. Harlow, and an omphacitite from an unknown locality (CM1/1), kindly provided by T. Boffa Ballaran, Pavia, Italy (Fig. 7). In all cases, the correspondence between estimated and experimentally measured compositions was satisfactory.
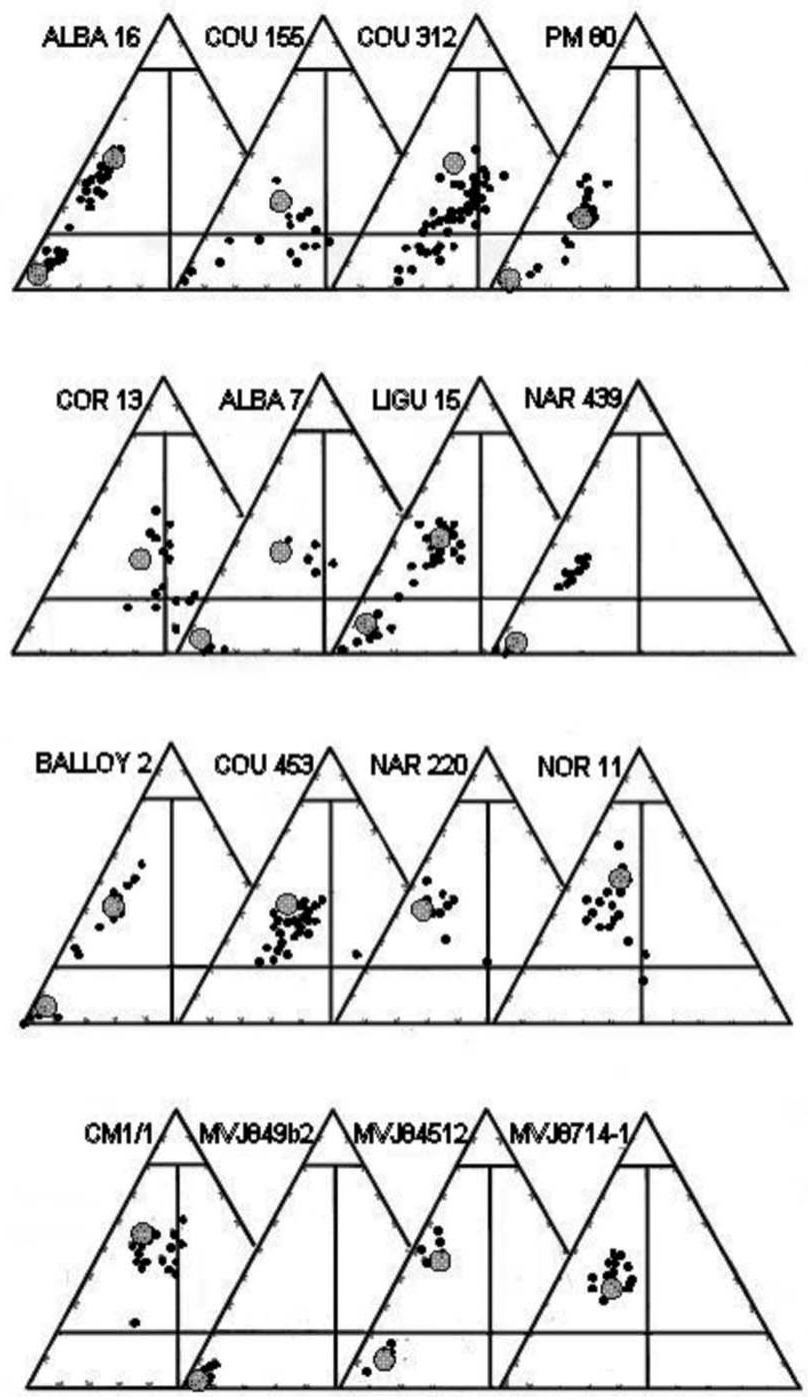

Figure 7

Comparison of the mean composition of Na-pyroxenes (estimated from the intersection on the compositional grid of the $d_{h k l}$ values of the three selected reflections) and the distribution of the SEM-EDS point analyses, performed on 16 specimens (12 Neolithic Alpine greenstone implements and 4 geological samples of analogous composition).

\section{Conclusions}

A new archaeometric approach is proposed to estimate the chemical composition of Na-pyroxene solid-solution series (in terms of percentage of the end-members Jd, Ae, Wo + En + Fs) on the basis of X-ray powder diffraction data only. Since the $d$ values of three selected reflections $(\overline{2} 21,310,002)$ vary systematically as a function of chemical composition, three independent sets of isoparametric lines were plotted on the clinopyroxene compositional triangle. By projecting the measured $d$ values on such a grid, the composition of a specimen can be estimated by the intersection of the related isoparametric lines. The selected reflections are intense, sharp and close to each other, thus facilitating the $d$ measure and reducing the data-collection time.

This approach allows one to obtain reliable quantitative chemical data without performing expensive and timeconsuming SEM-EDS analyses and - most importantly preserving the integrity of the sample, since only a very small quantity (a few $\mathrm{mg}$ ) of rock powder is needed to collect XRPD data. When a flat polished surface is present, there is no need for sampling, thus making this procedure totally non-invasive. The method is therefore particularly suitable for the study of Neolithic polished greenstone implements (which are largely composed of rocks bearing Na-pyroxene as a main component) for which non-invasive techniques are in many cases the only acceptable ones.

The authors are indebted to Marica Venturino Gambari and Monique Ricq-de-Bouard for their precious and invaluable cooperation. Special thanks to Roberta Oberti for providing single-crystal data of Na-pyroxenes and to Giovanna Occhiena, Ursula Perrone and Michele Borgogno for kindly sharing some of the SEM-EDS data. This project was in part financed by the Progetto Finalizzato Beni Culturali funds of CNR.

\section{References}

Bindi, L., Safonov, O. G., Yapaskurt, V. O., Perchuk, L. L. \& Menchetti, S. (2003). Am. Mineral. 88, 464-468.

Boffa Ballaran, T., Carpenter, M. A., Domeneghetti, C. \& Tazzoli, V. (1998). Am. Mineral. 83, 419-433.

Borgogno, M. (2000). Unpublished MSc Thesis, Università degli Studi di Torino, Italy.

Cameron, M. \& Papike, J. J. (1981). Am. Mineral. 66, 1-50.

Chiari, G. (2000). European Mineralogical Union Notes in Mineralogy, Vol. 2, edited by D. Vaughan \& R. Wogelius, ch. 10, pp. 351-381. Eötvos University Press.

Chiari, G., Compagnoni, R. \& Giustetto, R. (1996). Tracce, On-line Rock Art Bull. 5, http://www.rupestre.net/tracce/xray.html.

Chiari, G., Compagnoni, R., Giustetto, R. \& Ricq-de-Bouard, M. (1996). Le Vie della Pietra Verde. L'Industria Litica Levigata nella Preistoria dell'Italia Settentrionale, edited by M Venturino Gambari. Catalogo della Mostra, Torino, pp. 35-52.

Compagnoni, R., Giustetto, R., Ricq-de-Bouard, M. \& Venturino Gambari, M. (2006). Atti XXXIX Riunione Scientifica dell'Istituto Italiano di Preistoria e Protostoria, Firenze, 25-27 November 2004, pp. 655-682.

Compagnoni, R., Ricq-de-Bouard, M., Giustetto, R. \& Colombo, F. (1995). Boll. Museo Reg. Sci. Nat. Torino, 13, Suppl. 2, 329-359. 
D’Amico, C., Bargossi, G. M., Felice, G. \& Mazzeo, M. (1991). Mineral. Petrogr. Acta, 34, 257-283.

D'Amico, C., Campana, R., Felice, G. \& Ghedini, M. (1995). Eur. J. Mineral. 7, 29-41.

D'Amico, C., Felice, G., Gasparotto, G., Ghedini, M., Nannetti, M. C. \& Trentini, P. (1997). Mineral. Petrogr. Acta, 40, 385-426.

D'Amico, C. \& Ghedini, M. (1996). Museologia Sci. 13, Suppl., 292-312.

D'Amico, C. \& Starnini, E. (2006). Geol. Soc. London Spec. Publ. 257, 257-272.

D'Amico, C., Starnini, E. \& Voytek, B. A. (2000). Preistoria Alpina, 31, 91-124.

Damour, A. (1881). Bull. Soc. Fr. Minéral. 4, 157-164.

Davoli, P. (1986). Unpublished PhD thesis, Universitàdegli Studi di Modena, Italy.

Edgar, A. D., Mottana, A. \& Macrae, N. D. (1969). Mineral. Mag. 37, 61-74.

Ernst, W. G., Seky, Y., Onuki, H. \& Gilbert, M. C. (1970). Geol. Soc. Am. Mem. 124, 154.

Errera, M. (1999). Mus. R. Afr. Centr. Tervuren (Belg.) Dép. Géol. Min. Rapp. Ann. 1997-1998, 221-244.

Errera, M. (2002). Les Matières Premières Lithiques en Préhistoire, pp. 161-167. Aurillac: Table Ronde Internationale.

Franchi, S. (1900). Boll. Regio Comitato Geol. Italiano, 4, 119-158.

Gastaldi, B. (1871). Mem. Descr. Carta Geol. Italia, 1, 1-36.

Giustetto, R. \& Compagnoni, R. (2004). Alla Conquista dell'Appennino. Le Prime Comunità delle Valli Curone, Grue e Ossona, edited by $\mathrm{M}$. Venturino Gambari. Exhibition catalogue, Torino, Italy, pp. 45-59.
Griffin, W. L. \& Mottana, A. (1982). Am. Mineral. 67, 568-586.

Hauy, R. J. (1822). Traité de Minéralogie, 2nd ed., Vol. 2. Paris: Bechelier.

Lange, F. W. (1993). Precolumbian Jade: New Geological and Cultural Interpretations. University of Utah Press.

Laufer, B. (1946). Jade: a Study in Chinese Archaeology and Religion. New York: Dover Publications.

Mottana, A. (1983). Period. Mineral. 52, 427-461.

Nestola, F., Boffa Ballaran, T., Liebske, C., Bruno, M. \& Tribaudino, M. (2006). Phys. Chem. Miner. 33, 417-425.

Nestola, F., Tribaudino, M., Boffa Ballaran, T., Liebske, C. \& Bruno, M. (2007). Am. Mineral. 92, 1492-1501.

Occhiena, G. (1999). Unpublished MSc Thesis, Università degli Studi di Torino, Italy.

Pasqual, D., Molin, G. \& Zanazzi, P. F. (1995). Eur. J. Mineral. 7, 369-378.

Perrone, U. (1999). Unpublished MSc thesis, Università degli Studi di Torino, Italy.

Petrequin, P., Errera, M., Cassen, S. \& Croutsch, C. (2002). Les Matières Premières Lithiques en Préhistoire, pp. 253-275. Aurillac: Table Ronde Internationale.

Ricq-de-Bouard, M. (1981). Gallia Préhistoire, 24, 281-290.

Ricq-de-Bouard, M., Compagnoni, R., Desmond, S. \& Fedele, F. (1990). Gallia Préhistoire, 32, 125-149.

Ricq-de-Bouard, M. (1996). Monographie du CRA, No. 16, CNRS Editions, Paris.

Rock, N. M. S. (1990). Mineral. Petrol. 43, 99-119.

Sharer, R. J. \& Morley, G. S. (1995). The Ancient Maya. Stanford University Press. 